УДК 82:81-03

\author{
Чобанов Мушвиг, \\ диссертант Института литературы \\ имени Низами НАНА, Азербайджан
}

\title{
РАЗВИТИЕ АЗЕРБАЙДЖАНСКОЙ ДРАМАТУРГИИ В ГРУЗИИ
}

У статті представлено літературний пейзаж Азербайджанської драматургії в Грузії. Окрім изього, у статті розкриваються причини затримки розвитку изього жанру по відношенню до інших літературних жанрів. Посилаючись на літературні матеріали, розкривається коло ідеї-теми Азербайджанської драматургї̈ в Грузї. Слід зазначити, щзо далися взнаки відсутність протягом тривалого часу Азербайджанського начіонального театру в Грузії та драматичне спрямування Азербайджанської літератури стосовно інших жанрів. Якщо враховувати те, щзо $і$ в Азербайджані драматургія стосовно прози $і$ поезії булла слабко розвинена, то все стає зрозуміло. Проте в останні роки написані в Грузії твори обнадіюють і сповіщають про перспективне майбутнє Азербайджанської драматурги.

Ключові слова: драматургія, театр, Грузія, n'єса, література.

В статье представлен литературный пейзаж Азербайджанской драматургии в Грузии. Речь идет о направлениях развития драматургии. Раскрываются причины задержки развития этого жанра по отнотению $к$ другим литературным жанрам. Ссылаясь на литературные материаль, раскрывается значение идеи-темы Азербайджанской драматургии в Грузии. Следует отметить, что сказалось отсутствие в течение длительного времени Азербайджанского национального театра в Грузии и слабое развитие драматического направления Азербайджанской литературы по отношению к другим жанрам. Если учитывать, что и в Азербайджане драматургия по отношению к прозе и поэзии была слабо развита, тогда все становиться ясно. Но в последние годы написанные в Грузии произведения обнадеживают и извещают о благополучном будущем Азербайджанской драматургии.

Ключевые слова: драматургия, театр, Грузия, пьеса, литература.

The article presents the literary landscape of Azerbaijan drama in Georgia and directions of dramatic development. This paper reveals the reasons for the delay of this genre development in comparison to other literary genres. Referring to the literary material, it discloses the idea of a circle-theme Azerbaijan drama in Georgia. An explanation of the artistic problems is represented in the plays. Interestingly, if you look at the Azerbaijan literary environment in Georgia in 1960-1980. Respectively, in local print literary journals, literary agencies do not meet the dramatic or comic works. Finally, it should be noted that the absence of a long time Azerbaijan National Theatre in Georgia, has made it clear and the dramatic trend of the Azerbaijan literature in relation to other genres are poorly developed. If we consider that in Azerbaijan dramaturgy towards prose and poetry was poorly developed, then everything becomes clear. But in recent 
years, written works in Georgian are encouraging and they inform about the prosperous future of Azerbaijan playwrights.

Key words: drama, theater, Georgia, pieces, literature.

Несмотря на то, что основа нашей национальной драматургии была положена в 1872 году в Тбилиси, к сожалению, в последующих этапах ее развитие пошло не по возрастающей. Одной из главных причин этого, конечно, явилось отсутствие здесь в течении некоторого времени национального театра. А не обоснованное закрытие в 1944 году Тбилисского Государственного Азербайджанского Драматического Театра имени М. Ф. Ахундова в результате проблем, параллельно возникших от неродного отношения к Азербайджанскому театру в Грузии, оказало отрицательное влияние на развитие здесь драматургического жанра.

После закрытия Тбилисского Азербайджанского театра многие его создатели переехали в Баку и другие города, что привело к ослаблению драматургии в местной азербайджанской литературной среде. Интересно то, что если обратить внимание на азербайджанскую литературную среду 1960-1980 годов в Грузии, в здешних печатных литературных изданиях и литературных органах не встречаются драматические или комические произведения. В 1980-1990 гг. в Грузии в литературных сборниках и альманахах опубликованы всего лишь два драматических произведения. Автором обоих произведений является Азим Исмаиллы.

Опубликованная в литературном сборнике «Чешме» первая пьеса «Пара фиалок» (из четырех актов, семи картин) рассказывает о событиях Второй мировой войны [Биннатоглу 2006]. В литературном сборнике «Утренняя звезда» (1989) опубликовано второе драматическое произведение - одноактная пьеса «Мертвые и живые», написанная Мирза Джалилом, который через сто лет в воспоминаниях встречается со своими героями [Дан улдузу 1989]. Как видно, наблюдаемые в конце XX века успехи в области поэзии и прозы невозможно отнести к области драматургии. И поэтому нужно согласиться с мнением литературоведа Ш. Шамоглу, утверждающего, что «в литературной среде Борчальл драматургия никогда не была ведущуим жанром» [Чешме 1980:104]. 
А после ремонта и восстановления, при поддержке фонда Гейдара Алиева, в начале XXI века - в 2004 году Грузинского государственного Азербайджанского Драматического театра имени М. Ф. Ахундзаде, вновь появился большой интерес к драматургии в азербайджанских драматургов, проживающих в Грузии. В последние годы один за другим издавались и представлялись театрам пьесы мастеров пера, проживающих в Грузии, М. Х. Бахтиярлы, Азим Исмаиллы, Дунямалы Карам, Алхан Биннатоглу, Имир Мамедли, Муса Заргерли, Азиз Даливелли и других. Произведения известных мастеров - М. Х. Бахтиярлы стихотворная драма «Сабир», Имира Мамедли комедия «Ключ», Мусы Заргерли «Сон», «Зор-ребенка зор беда», «Пусть приходит начальник» музыкальные комедии, «Судьба одной семьи» и «Дни страдания» драмы, Азиза Даливелли «Кровь мучеников не остается на земле» стихотворная пьеса и др. были встречены читателями с большим интересом. Некоторые из этих произведений были поставлены в Тбилисском драматическом театре. Еще впервые в 1980-е годы, испытав себя в области драмы, А. Исмаиллы в последующем написал несколько произведений. Его творения под названием «Слезы радости» и «Тени светятся», были представлены публике в Мингячевирском государственном драматическом театре им. Давудова [Дунямалы 2004]. В основном, будучи известным как поэт Дунямалы Карам, обращаясь и к драматургии, написал пьесы под названием «Сватовство» и «Операция очищения». Эти произведения были включены в книгу драматурга «Пьесы» (2004). В комедии «Сватовство», состоящей из 5-и актов и 7-и сцен, говориться о том, как в конце XX века, начале XXI века спекулянты в районных исполнительных властях (гамгеоба), сельсоветах (сагре-було) во время проведения земельной реформы занимались куплей продажей земли. Территория, где происходят эти события и все персонажи основаны на реальных фактах. Эти спекулянты, имеющие депутатов родственников во власти, под предлогом «покупки» приватизируют плодородные и орошаемые пахотные земли, где компактно проживают азербайджанцы. Создают «СПС» - крупные предприятия. Их лидеры - 
представители господствующей нации - каждый гектар земли за 500 (пятьсот) долларов в год сдают в аренду безземельным крестьянам - азербайджанцам. Каждой главе семьи, для показухи, за 200 (двести) долларов продают 0,20-0,25 га садовой площади.

Драматург в пьесе «Сватовство» разоблачает через собственные разговоры таких как Муслим, отставший от современной жизни, безграмотный, занимающейся мошенничеством, как Мохсун, бесчестный, присваивающий народное добро, скот, порубивший виноградники руководителей совхозов.

Драма «Операция очищения» из 5-и актов и 14-и сцен описывает античеловеческие события, проводимые Коммунистической партией в 20-30-х годах под лозунгом - «Ликвидировать помещичество как класс». В произведении разоблачаются аномальные решения, принятые на XVI партийной конференции под названием - «очистить ряды партии от ТротцкийЗиновевцев». Позже это решение применяется ко всем трудящимся, рабочим, крестьянам и интеллигенции. Все перечисленные в пьесе названия сел и персонажей являются реальными. Главный герой произведения Джошгун, сам писатель, а Кебир его отец, женщина с родинкой - его мать Хатун. Драматург написал о тех трагических днях, которых пережила его семя в те трагические годы, и это ему более менее удалось.

Автор в своем произведении также показывает, что наряду с коммунистами и комсомольцами во волчьей шкуре были и мужественные и гуманные большевики, протягивающие руку помощи беспомощным, подвергающимся клевете трудолюбивым людям. Как говорится: иногда в колючках и розы растут. Житель села Гжлынджлы дед Наиб (Насиб Набиоглы) является ярким представителем этого. Он говорить с начальником районного отдела НКВД Люксембургского (ныне Болниси) района. Кабира с музыкой доставляет НКВД, сдает его винтовку, выпускает на свободу, с музыкой возвращает назад. В партократские годы была поговорка - «Советская власть кролика ловит повозкой». На самом деле, не проходя 7-8 месяцев Кабира 
арестуют как «врага народа» и ссылают в Сибирь. И он больше назад не возвращается [Чобанлы 2010].

Один из персонажей в произведении, который привлекает внимание, это дед Наиб. Он является живым образом, проживающего в селе писателя, Насиба Набиоглу. Его по настоянию отбросов общества ... обвиняли в неправильном распределении пшеницы, приходящего на трудовые дни и освободили от должности председателя колхоза. Однако, учитывая отличную репутацию среди людей его снова вернули на свою должность. Он, сообща с секретарем первичной партийной организации Асланом, директором школы Джошгуном колхоз выводят в ряд передовых в регионе. Несмотря на то, что в пьесе Алхана Биннатоглу «Камень для посланника» (2006), автор обращается к прошлому, не указывается конкретное историческое время и место, в определенной степени допускается анахронизм. Основной целью этой драмы, написанной по исторической теме, состоящей из четырех актов является искренняя любовь к священной родине, бесконечная любовь к отчизне, связанность с народом, патриотизм, освобождение от зависимости чужих стран. В драме кроме 14-и главных персонажей имеются девочки танцовщицы, музыканты, городские люди, заключенные, солдаты, дворцовые люди, храбрецы, одним словом имеется богатая галерея персонажей [Шамыоглу 2009].

Профессор Мадад Чобанов написание поэтом в жанре драматургии, отличающихся содержанием и историчностью драматических произведений высокого уровня, не оценивая как случайность пишет: «Потому, что если глубже рассматривать его поэтические произведения в большинстве его стихах можно было чувствовать элементы драматизма. А с другой стороны, среди прочитанных им произведений драматических произведений не мало и это создало условие для того, чтобы он когда то выступал как драматург» [Чобанлы 2010].

А руководитель художественной части Тбилисского государственного азербайджанского драматического театра Эмин Махмудов выступление А. Биннатоглу как драматург связывает с развитием театра: «Восстановление и 
снова начавший работать, имеющий славную историю театра ... примерная работа, проделанная в течение года, приносит свои плоды и эта драма А. Биннатоглу оставляет символическое впечатление первой ласточки, предвещает о том, что в будущем возникнут много таких драм-пьес... С точки зрения актуальности темы, сложности периода сегодня Азербайджанской сцене нужны лишь такие произведения, заполненные такими патриотическими чувствами представления. Лишь поэтому я считаю возможным и важным подготовку драмы «Камень для посланника» к представлению» [Чобанлы 2010]. Если сюда добавить и существующий в Грузии Абхазский, Самачаблонский конфликты, то не остается никакой необходимости серьезно разъяснить, что она превратиться в любимое публикой, усиливающее чувство патриотизма, представление. Широкое использование наших старинных музыкальных инструментов, песен еще немного увеличивает ее силу действия и это может привести к высокой степени желаемому результату при жизни на сцене. Е. Махмудов это произведение считает достойным быть в одном ряду с произведениями, созданными И. Эфендиевым, Бахтияром Вагабзаде, Нариманом Гасанзаде и другими передовыми драматургами на историческую тему. В первом драматическом произведении Алхана Биннатоглу «Камень для посланника», состоящем из четырех актов, находят свое широкое художественное отражение историческое прошлое наших предков и его славные страницы. В произведении оживают перед глазами боевое и полное героизма историческое прошлое, почетный жизненый путь - «Сага о Билгамыш», «Книга Деде Коркут» и эпос о «Манасе», знаменитые писменные памятники Орхан-Енисей, «Огузнаме», а также в целом, прошедший испытание историей, боевой путь турецко-шумерского мира, патриотический дух и чувство приверженности к земле, отчизне, традиции, борьба добра и зла, советы и благословения мудрых отцов и матерей, призывающий древний дух Отца Шамана, Деде Коркута, дочери Священника и советы, рекомендации десятков других, батальные сцены доблестных сыновей, с жаждой победы 
бросившиеся в бой как лев, а также Джаваншира, Бабека, Узун Гасана, Хатаи, Джавад хана, Кероглу,

Мехрали бей, Самадага, Беглец Isaxana, генерала Шихлинского, генерала Самедбеу Мехмандарова, генерала Ази Асланова, потрясшего Европу «Михайло».

Историчность и литературные заслуги драмы «Камень для посланника» этим не заканчиваются. У произведения много таких заслуг: несмотря на то, что в произведении место и время происходящих событий конкретно не указано, из общего содержания драмы, впервые в истории человечества, положившего основу культуры и возрождения народа межречья-шумэры и территории проживания древних тюрков, будучи по происхождению, языку, обычаю их родственниками, (Восточная Европа, Кавказ, Малая и Средняя Азия, Северо-Восточная Азия), исторически отличающиеся друг от друга времена, в общем сюжете и содержании произведения даны с такой системой и последовательностью, что читатель или зритель с первого мгновения представляет, что события происходят в одно и то же время. Например, несмотря на то, что Отец Шаман относиться к периоду до н. э., дочь Священника и сын Халвачы из поколения Низами, представлена как представители XII-XIII веков.

Образы дочь Священника и Отец Шаман в произведении с точки зрения нашего исторического прошлого предков очень живые и интересные образы. По мере раскрытия внутреннего мира образов (а в будущем, дай бог, зритель), читатель, со всем существом верит тому, что мудрые как сама жизнь, знающие тайны небес и земли шумерские сыны являются его предками и он принадлежит древнему турецкому поколению, тем самым испытывает законную гордость. Отведение особого места корням происхождения нашего народа - идея продолжения поэтического наследия Ильяса Юсифоглу в творчестве Халвачыоглу, является основной заслугой драмы.

Произведение построено вокруг интересных сюжетов. Разговорный язык между Отцом Шаманом и дочерью Священника, шумерский язык - 
представлен как язык наших предков, как свой турецкий язык. Один аспект тоже представляет серьезный интерес, что автор в своей книге, являющейся продуктом художественного мышления, смело высказывает такую историческую мысль, безусловно взял за основу очень объективные суждения ученых шумерологов и тюркологов мира и опирался на суждения исследователей С. Н. Крамера, С. Ллайда, Г. Чаулды, Г. Винклера, Е. Реклю, Д. Редера, Ахмет Джавата, О. Сулейманова, Е. Алибекзаде, А. Мамедов и других. Потому что они - предполагаюшие, что «культура начинается от шумеров», не ошибались. Таким образом, по происхождению шумеры являются родственниками турков, а также с генеалогической и типологической точки зрения их языки тоже родственные языки. Эта смелая идея автора тоже достойна похвалы и оценки. Это является самосознанием и возвращением к своим корням.

В центре всех эпизодов, описанных в произведении, в основном, стоит идея и дух тюркизма и азербайджанизма и интересы народа всегда выдвигается на первый план. Себялюбие, равнодушие к интересам страны, народа, ради личных интересов проклинаются, переворачивается вверх дном. Без сомнения, это приводит к разгрому коварных мыслей врага. И еще с точки зрения современности и актуальности значение произведения в том, что в ходе различных событий была достигнута четырех побед подряд.

Наконец, следует отметить, что отсутствие в течение длительного времени Азербайджанского национального театра в Грузии дало знать о себе и в драматическом направлении Азербайджанской литературы, развитой слабо в сравнении с другими жанрами. Однако не смотря на отсутствие драматургии в последние годы наблюдается интерес к драме, a написанные в Грузии произведения обнадеживают и извещают о благополучным будущем Азербайджанской драматургии.

\section{БИБЛИОГРАФИЯ}

Биннатоглу 2006 - Биннатоглу А. Камень для посланника / А. Биннатоглу. - Баку : Борчалы, 2006. - 120 с. 
Дан улдузу 1989 - Дан улдузу. Литературный сборник. II книга Тбилиси : Мерани, 1989. - 350с.

Дунямалы 2004 - Дунямалы К. Пьесы / К. Дунямалы. - Баку : Борчалы, 2004. $-147 \mathrm{c}$.

Исмайыллы 1989 - Исмайыллы А. Вчерашнее поминовение /

А. Исмайыллы. - Тбилиси : Мерани, 1989. - 299 с.

Шамыоглу 2009 - Шамыоглу Ш. Литература после «Золотой эры»/ Ш. Шамыоглу. - Баку : Наука и образование, 2009. - 207 с.

Чешме 1980 - Чешме. - Тбилиси : Мерани, 1980. - 257 с.

Чобанлы 2010 - Чобанлы М. М. Мир поэзии Дунямалы Керем / М. М. Чобанлы. - Баку : Борчалы, 2010. - 53 с.

Чобанлы 2010 - Чобанлы М. М. «Поэты Бог слова мира!..» (о творчестве Алхана Биннатоглу) / М. М. Чобанлы. - Баку : Борчалы, 2010. - 166 с. 